\title{
Community structure of intertidal boulder-cobble fields in the Straits of Magellan, Chile*
}

\author{
CARLOS RÍOS and ERIKA MUTSCHKE \\ Instituto de la Patagonia, Universidad de Magallanes, Casilla 113-D, Punta Arenas, Chile. \\ E-mail: crios@aoniken.fc.umag.cl
}

\begin{abstract}
SUMMARY: Based on quantitative samples taken along 4 transects in mobile hard-bottom intertidal areas of the Canal Whiteside, Magellan region, biotic composition, abundance and distribution patterns are described. The intertidal substrates, mainly formed by boulders and cobbles, represent highly heterogenous habitats from the structural point of view, and demonstrated a species richness higher than previously mentioned in some preliminary reports. Community structure parameters (abundance, species richness, diversity, and evenness) were not homogenous in the study areas, suggesting local dynamics. Differences in the vertical distribution of organisms were also found, suggesting changes of the zonation pattern along the beach profile. The macrofaunal assemblages were dominated by few species, with different specific compositions between transects. In general, representatives of Mollusca (Mytilus chilensis, Perumytilus purpuratus), Polychaeta (Hemipodus simplex), and Amphipoda (Paramoera fissicauda, P. brachyura, Transorchestia chilensis) were the numerically dominant groups. In terms of biomass, molluscs were highly dominant, mainly $M$. chilensis and $P$. purpuratus. Among the macroalgae, rhodophytes were the group with the highest presence, but Ulva lactuca (Chlorophyta) was the dominant species. In the upper sandy terrace, no macroorganisms were found. Several species found at Canal Whiteside have a wide circumpolar distribution in Sub-Antarctic regions.
\end{abstract}

Key words: Magellan region, diversity, intertidal zone, boulder-cobble beach, benthos.

RESUMEN: ESTRUCTURA DE LA COMUNIDAD EN CAMPOS INTERMAREALES DE BLOQUES Y CANTOS DEL ESTRECHO DE MAGALLANES, CHILE. - A partir de muestras cuantitativas tomadas en cuatro transectos paralelos a la línea de costa, se describe la composición biótica y los patrones de distribución y abundancia de una comunidad intermareal presente en ambientes de fondos duros móviles en el Canal Whiteside, Región de Magallanes. El sustrato intermareal, formado principalmente por bloques y cantos, representa un hábitat altamente heterogéneo y mantiene una riqueza de especies mayor que la mencionada en algunos informes preliminares. Algunos parámetros de la estructura comunitaria (abundancia, riqueza de especies, diversidad y equitabilidad) mostraron diferencias en el área estudiada, sugiriendo dinámicas locales. Se encontraron diferencias en la distribución vertical de los organismos, sugiriendo cambios en el patrón de zonación a lo largo de la playa. La comunidad estuvo dominada por unas pocas especies, aunque la composición específica variara entre transectos. Los grupos numéricamente dominantes fueron Mollusca (Mytilus chilensis, Perumytilus purpuratus), Polychaeta (Hemipodus simplex) y Amphipoda (Paramoera fissicauda, P. brachyura, Transorchestia chilensis). En biomasa, los moluscos, principalmente $M$. chilensis y $P$. purpuratus fueron altamente dominantes. Entre las macroalgas, el grupo de las Rhodophyta fue el más representativo aunque Ulva lactuca (Chlorophyta) fue la especie dominante. En la parte superior arenosa de la playa no se encontraron macroorganismos. Varias especies encontradas en el Canal Whiteside muestran una amplia distribución en la zona subantártica.

Palabras clave: Región de Magallanes, diversidad, zona intermareal, playas de bloques y cantos, bentos.

*Accepted March 9, 1999. 


\section{INTRODUCTION}

Along the shoreline of the Magellan region, a typical and representative mobile hard-bottom substrate is formed by boulder-cobble intertidal fields, originated by glacial processes about 12,000 years ago (Clapperton et al., 1995). From a structural point of view, this type of physical habitat can be considered as an intermediate situation between soft substrate (e.g. sandy beaches) and typical hard-bottom substrate (i.e. rocky shores).

Initial studies in this intertidal habitat started after the 1974 "Metula" oil spill in the Straits of Magellan (see Guzmán and Campodónico, 1981). More recently, some community characteristics have been preliminarily described in areas located at the Cape Horn Archipelago (Ríos and Guzmán, 1982; Guzmán and Ríos, 1986 ) and at several sites in the Strait of Magellan (Ríos and Gerdes, 1997; Ríos and Mutschke, 1995; Mazzella and Gambi, 1993). A low species richness and diversity has been reported especially for some sites in the Straits of Magellan (BenedettiCecchi, 1996). Recently, Benedetti-Cecchi and Cinelli (1997) have shown inconsistency in patterns of vertical distribution (i.e. no general pattern of zonation) of macroalgae and invertebrates in rocky intertidal sites in the Straits of Magellan.

Specific studies have been developed on individual growth, reproductive biology, and distribution and abundance of some dominant boulder-cobble intertidal species (Guzmán and Ríos, 1987; Ríos et al., 1987; Santana, 1997; Guzmán, 1978; Langley et al., 1980; Miranda and Acuña, 1979).
The aim of this paper is to provide, in a broad sense, a description of the macrofaunal and floral assemblages and their distribution and density patterns, based on surveys carried out in a boulder-cobble intertidal system located in a secondary branch of the Straits of Magellan. Analysis of vertical distribution patterns of species in this intertidal habitat was done in order to define zonation patterns, which are known from other intertidal boulder-cobble fields (e.g. Ríos and Guzmán, 1982; Guzmán and Ríos, 1986) in the Magellan region. Finally, our results are compared with information reported from other Subantarctic areas.

\section{MATERIAL AND METHODS}

Data used in this paper were collected during November 1994 in Canal Whiteside, located in the eastern part of Isla Tierra del Fuego (Fig. 1). Canal Whiteside is considered as one of the two secondary basins, which branch off from the basin of Punta Arenas. It is about $90 \mathrm{~km}$ long and 10-15 km wide (Brambati et al., 1991). No information is avaliable in relation to hydrography or biological features of this area.

In the sampling area, the intertidal zone consisted physically of an upper sandy-gravel beach and a terrace of boulder-cobble substrate, originated from deglaciation processes, which occurred in the Magellan region ca. 12.000 years ago (Uribe, 1982). In this area, boulders and cobbles rest on a sandy-sediment matrix (Fig. 2). Types of sediments are classi-

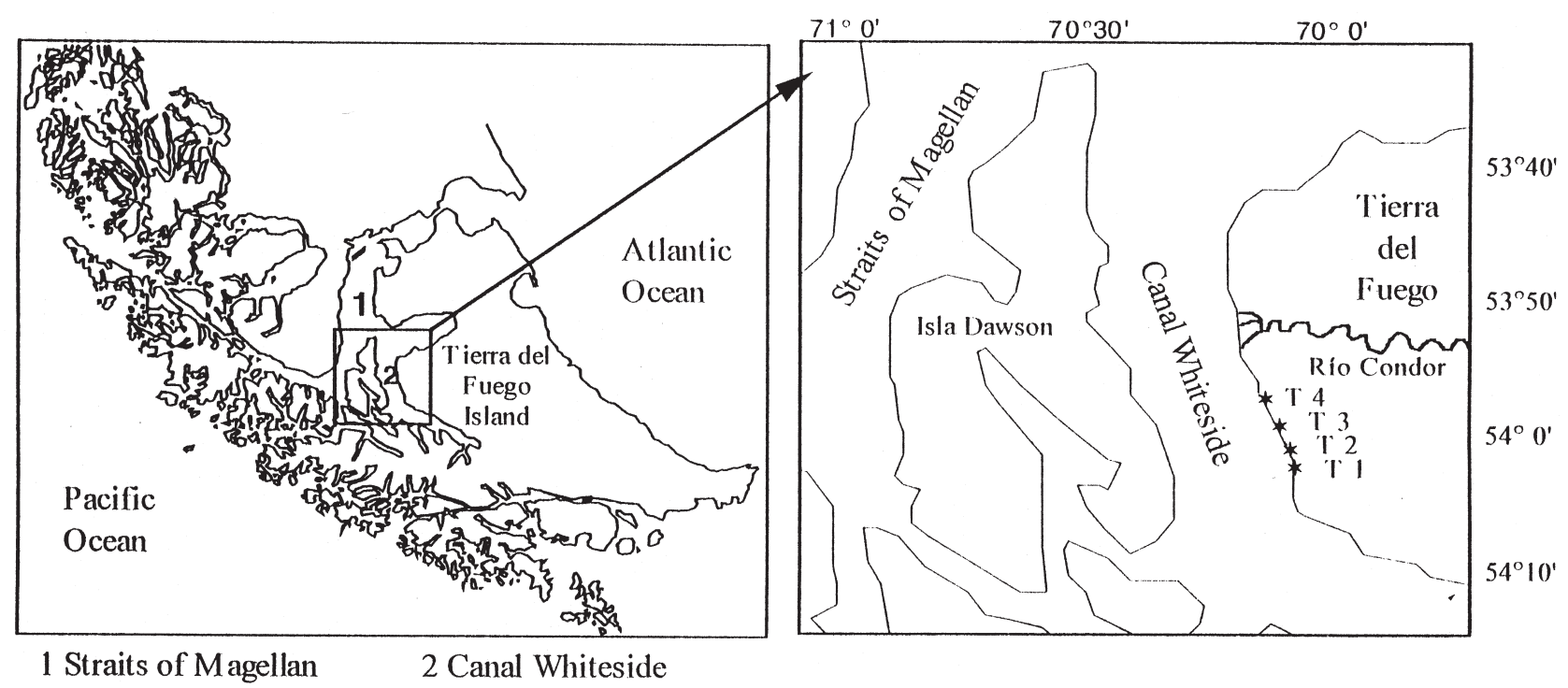

FIG. 1. - Map of the southern tip of South America showing the Magellan Region and the sampling area of this study. 

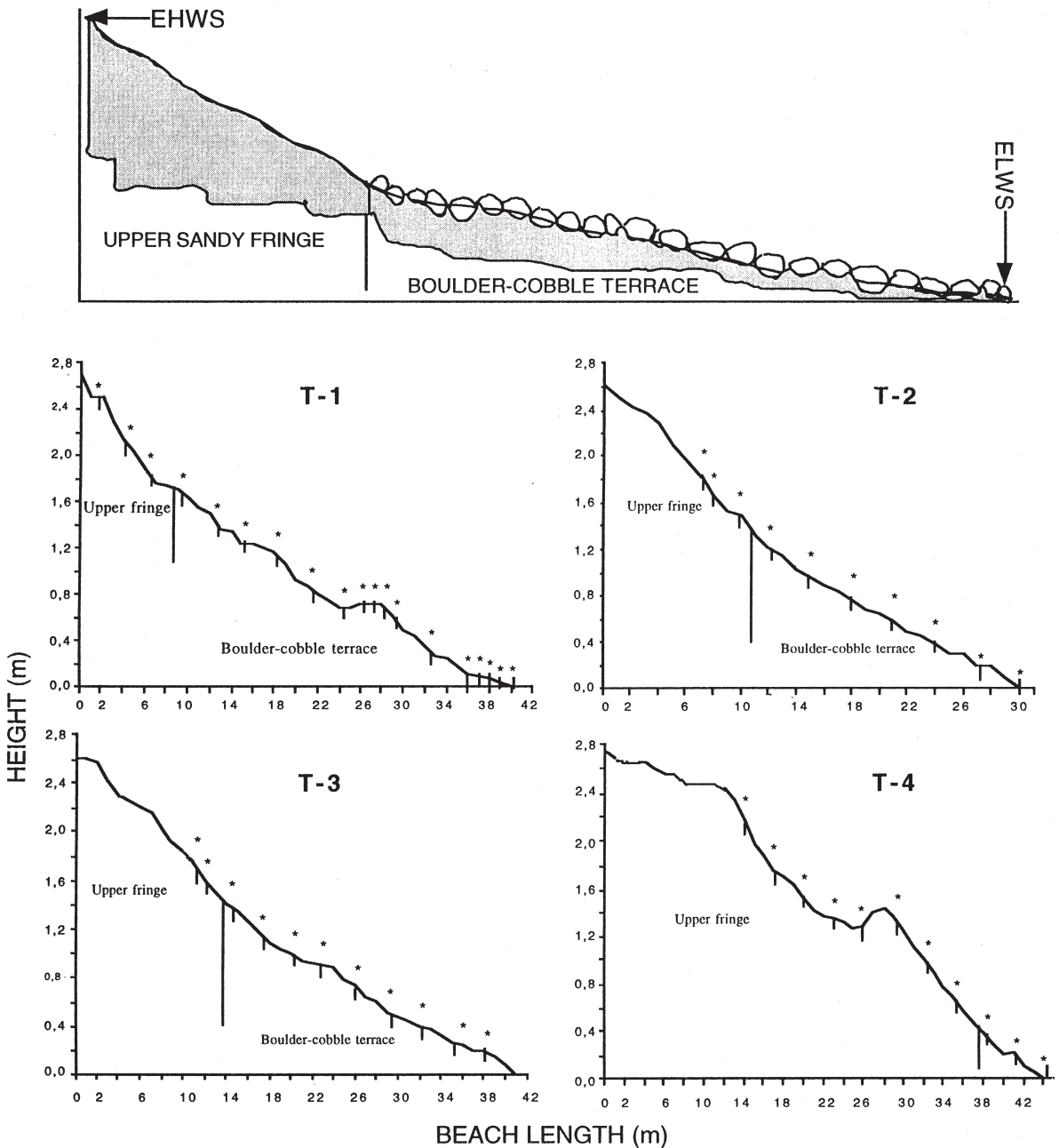

FIG. 2. - Scheme of a typical boulder-cobble intertidal zone in Canal Whiteside (a) and of the beach profiles in the four sampled transects (T1-T4) (b). EHWS = extreme high tide level for spring tide; ELWS = extreme low tide level for spring tide. (*specific sampling points).

fied according to the Wentworth grade classification (Buchanan, 1984).

Four transects of the beach separated by $1 \mathrm{~km}$ each and differing in the length of the upper sandy fringe and boulder-cobble terrace were selected to describe distribution and abundance patterns of macroalgae and macrofauna. In each transect, samples were taken in lines $4 \mathrm{~m}$ wide each, running perpendicular to the shoreline from the top of the intertidal zone to about mean low tide level. Transect profiles (Fig. 2) were done according to Emery's (1961) method.

Specific sampling points along the transect profiles (see positions in Fig. 2) were determined by the beach width during low tide. In the upper sandy fringe, three random samples of sediment were collected in each sampling point using squares of $50 \mathrm{x}$
$50 \mathrm{~cm}$ and $15 \mathrm{~cm}$ (sandy sediments) or $20 \mathrm{~cm}$ depth (boulder-cobble area). They were sieved in situ over $1 \mathrm{~mm}$ mesh size to retain the macrofauna. In the boulder-cobble terrace a mixture of sampling procedures was employed, but always three random samples were taken at each sampling point. First, all the macroorganisms attached or found on the undersurface, sides or below the boulders or cobbles, present on a surface of $0.25 \mathrm{~m}^{2}$ were manually collected. In a second step, each boulder or cobble inside the 0.25 $\mathrm{m}^{2}$ surface was lifted onto its side or overturned and all the sediment below was collected and sieved in situ over $1 \mathrm{~mm}$ mesh size to sort the macroinfauna fraction. All sorted biological material was fixed in $5 \%$ buffered formalin for later analysis.

Distribution and abundance of macroalgae and cirripedes along each transect were evaluated by 
TABLE 1. - Mean abundance of macroalgae (\% of coverage including Cirripedia) and total number (N) and biomass (B; g) of animal species or major taxa (presented as N/B) collected in the four transects (T1-T4) of Canal Whiteside.

\begin{tabular}{|c|c|c|c|c|}
\hline Transects/Taxa & $\mathrm{T}-1$ & $\mathrm{~T}-2$ & $\mathrm{~T}-3$ & $\mathrm{~T}-4$ \\
\hline \multicolumn{5}{|l|}{ Macroalgae } \\
\hline \multicolumn{5}{|l|}{ Chlorophyta } \\
\hline Urospora penicilliformis (Roth) Areschough & 2 & 8 & - & - \\
\hline Ulva lactuca Linnaeus & 12 & - & 1 & 23 \\
\hline $\begin{array}{l}\text { Acrisiphonia pacifica (Montagne) J. Agardh } \\
\text { Enteromorpha sp. }\end{array}$ & - & 1 & - & - \\
\hline Enteromorpha sp. & - & - & 1 & - \\
\hline \multicolumn{5}{|l|}{ Rhodophyta } \\
\hline $\begin{array}{l}\text { Porphyra columbina (Montagne) } \\
\text { Iridaea tuberculosa (Hooker \& Harvey) Leister }\end{array}$ & 5 & 12 & 1 & - \\
\hline Dasyptilon harveyi (J.D. Hooker) Papenfuss & $\begin{array}{l}1 \\
1\end{array}$ & 1 & 7 & $\begin{array}{c}- \\
-\end{array}$ \\
\hline Ceriamum dozei Hariot & - & - & 1 & - \\
\hline Ptilonia magellanica (Montagne) J. Agardh & - & - & 7 & - \\
\hline Stictosiphonia hookeri Hooker & 1 & - & - & - \\
\hline Delesseria lancifolia (Hooker \& Harvey) J. Agardh & - & - & - & 2 \\
\hline Polysiphonia anisigona J.D. Hooker \& Harvey & - & - & - & 4 \\
\hline \multicolumn{5}{|l|}{ Phaeophyta } \\
\hline Caepidium antarcticum J. Agardh & 1 & $\overline{-}$ & - & - \\
\hline Pilayella littoralis (L.) Kjellmann & - & 2 & - & - \\
\hline Scytosiphon lomentaria (Lyngbye) J. Agardh & - & 1 & 1 & - \\
\hline Adenocystis utricularis (Bory) & - & 1 & 1 & - \\
\hline Sphacelaria bornetti Hariot & - & - & 4 & - \\
\hline \multicolumn{5}{|l|}{ Macrofauna } \\
\hline Anthozoa & $24 / 6.1$ & $1 / 0.3$ & - & $93 / 15$ \\
\hline Turbellaria & $121 / 0.7$ & $99 / 0.3$ & $21 / 0.13$ & $7 / 0.012$ \\
\hline Nematoda & $20 / 0.09$ & $17 / 0.02$ & - & $3 / 0.0001$ \\
\hline Nemertini & $48 / 8.4$ & $50 / 5.4$ & $3 / 0.35$ & $81 / 6.7$ \\
\hline Oligochaeta & $5 / 0.07$ & - & - & - \\
\hline \multicolumn{5}{|l|}{ Polychaeta } \\
\hline Neoleprea sp. & $11 / 1.4$ & - & & \\
\hline Thelepus setosus (Quatrefages, 1866) & $41 / 5.3$ & - & $5 / 1.3$ & $17 / 3.9$ \\
\hline Platynereis australis (Schmarda, 1861) & $21 / 4.1$ & - & $1 / 0.02$ & $17 / 3.1$ \\
\hline Hemipodus simplex (Grube, 1857) & $63 / 6.6$ & - & $4 / 0.8$ & $15 / 1.6$ \\
\hline Eunoe sp. & $24 / 0.4$ & - & - & $1 / 0.1$ \\
\hline Harmothoe sp. & $5 / 0.2$ & - & - & $4 / 0.5$ \\
\hline Perinereis falklandica (Ramsay, 1914) & - & - & - & $1 / 0.07$ \\
\hline Eteone sculpta Ehler, 1897 & $1 / 0.1$ & - & - & - \\
\hline Nicolea chilensis (Schmarda, 1861) & - & - & - & $3 / 0.4$ \\
\hline Nereis callaona (Grube, 1857) & - & - & - & $5 / 0.3$ \\
\hline Nereis eugeniae (Kinberg, 1866) & $3 / 1.5$ & - & - & $3 / 0.1$ \\
\hline \multicolumn{5}{|l|}{ Bivalvia } \\
\hline Aulacomya ater (Molina) 1782 & $11 / 41.1$ & & & - \\
\hline Mytilus chilensis (HupE, 1840) & $353 / 4423$ & $2580 / 1447$ & $1555 / 2437$ & $4464 / 9654$ \\
\hline Perumytilus purpuratus Lamarck, 1819 & $330 / 1379$ & $2687 / 932$ & $924 / 724$ & $88 / 68.1$ \\
\hline Clausinella gayi (HupE) 1854 & $15 / 23.4$ & - & - & - \\
\hline \multicolumn{5}{|l|}{ Gastropoda } \\
\hline Collisella sp. & $3 / 0.4$ & - & $9 / 1.5$ & \\
\hline Nacella deaurata (Gmelin, 1791) & $109 / 305.1$ & - & $10 / 28.6$ & $11 / 6.3$ \\
\hline Nacella magellanica (Gmelin, 1791) & $111 / 494.6$ & - & $30 / 191.7$ & $11 / 71.1$ \\
\hline Nacella flammea (Gmelin, 1791) & $13 / 18.8$ & - & - & $3 / 1.9$ \\
\hline Nacella sp. & $7 / 24.4$ & - & - & - \\
\hline Fissurella picta (Gmelin, 1791) & $9 / 73.9$ & - & - & - \\
\hline Fissurella sp. & & - & - & $1 / 5.1$ \\
\hline Ximenopsis muriciformis (King \& Broderip, 1831) & $1 / 1.9$ & - & - & - \\
\hline Plaxiphora aurata (Spalowsky, 1795) & $1 / 0.9$ & $1 / 0.3$ & - & - \\
\hline Chiton sp. & $1 / 0.3$ & & - & - \\
\hline Siphonaria lessoni (Blainville, 1824) & $3 / 0.7$ & $3 / 3.2$ & $28 / 11.5$ & 71077 \\
\hline Acanthina monodon (Solander, 1786) & - & - & - & $7 / 29.7$ \\
\hline Trophon geversianus (Pallas, 1769) & - & - & - & $3 / 5.3$ \\
\hline Isopoda & & & & \\
\hline Exosphaeroma gigas (Leach, 1814) & $1 / 0.01$ & $1 / 0.01$ & $60 / 0.86$ & $13 / 0.2$ \\
\hline Serolis sp. & $1 / .003$ & - & - & - \\
\hline $\begin{array}{l}\text { Amphipoda } \\
\text { Transorchestia chiliensis (Milne-Edwards 1840) }\end{array}$ & & & & \\
\hline $\begin{array}{l}\text { Transorchestia chiliensis (Milne-Edwards, 1840) } \\
\text { Paramoera fissicauda (Dana, 1852) }\end{array}$ & $216 / 5.3$ & $36 / 0.9$ & $553 / 1370$ & - \\
\hline $\begin{array}{l}\text { Paramoera fissicauda (Dana, 1852) } \\
\text { Paramoera brachyura Schellenberg, } 1931\end{array}$ & $\begin{array}{l}524 / 9.3 \\
121 / 0.8\end{array}$ & $15 / 0.2$ & $\begin{array}{l}533 / 13.19 \\
228 / 0.5\end{array}$ & - \\
\hline Paramoera pfeferi Schellenberg, 1931 & - & - & 200 & $17 / 0.2$ \\
\hline Hyale hirtipalma (Dana, 1852) & - & - & $5 / 0.08$ & $113 / 1.2$ \\
\hline Decapoda & & & & \\
\hline Acanthocyclus albatrossis Rathbun, 1898 & $13 / 10.8$ & - & $9 / 2.53$ & $19 / 4.6$ \\
\hline Halicarcinus planatus (Fabricius) 1793 & $1 / 0.3$ & - & & $1 / 0.07$ \\
\hline Pagurus sp. & $10 / 0.13$ & - & $1 / 0.0003$ & - \\
\hline Peltarion spinosulum (White) & $3 / 1.2$ & - & - & - \\
\hline Cirripedia & & & & \\
\hline $\begin{array}{l}\text { Chthamalus scabrosus Darwin, } 1854 \\
\text { Asteroidea }\end{array}$ & 5 & - & 4 & 23 \\
\hline $\begin{array}{l}\text { Asteroidea } \\
\text { Anasterias antarctica (L tkam, 1886) }\end{array}$ & $29 / 309$ & _ & $8 / 116$ & $25 / 43$ \\
\hline Echinoidea & 29100.9 & - & & \\
\hline Pseudechinus magellanicus (Phillipi, 1857) & & - & - & $3 / 17.3$ \\
\hline Holothuroidea & $57 / 4.1$ & - & - & $3 / 0.2$ \\
\hline $\begin{array}{l}\text { Pisces } \\
\quad \text { Harpagifer bispinis (Schneider) }\end{array}$ & $1 / 6.9$ & - & - & - \\
\hline
\end{tabular}


cover estimations using an optically-sighted pointframe of $0,25 \mathrm{~m}^{2}$, with 100 points defined by superimposed pairs of cross wires. At each sampling point, three of the four squares were evaluated.

All collected animals of each species or major taxon were counted and their wet weight was determined after blotting on filter paper until dry. Mean abundance and biomass data of each species or of major taxa (on $\mathrm{m}^{2}$ basis) were calculated for each sampling point.

Numerical procedures employed for the analysis of the biological data were performed using the Plymouth Routine In Multivariate Ecological Research (PRIMER) computer package (Clarke and Warwick, 1994). Using logarithms to base " $\mathrm{e}$ " indices of species richness (Margalef's d), Shannon-Wiener diversity (H') and evenness (Pielou's $\mathrm{J})$ were calculated and the significance of the differences between transects was tested by one way ANOVA. Comparisons among values were done with the unplanned multiple comparison test LSD (Least Significant Difference; Sokal and Rohlf, 1995). Hierarchical clustering technique (PRIMER routine CLUSTER) was used to discriminate groups of samples and to show faunistic zonation patterns along the beach profiles of transects 1,2 , and 3. Transect 4 was not considered in the analysis due to the physical features of the beach which allowed samples to be taken at only three sampling points (see Fig. 2). Similarity was estimated by the Bray and Curtis (1957) similarity coefficient measure for double square-root transformed species abundance data.

\section{RESULTS}

An important feature of all transects was the total absence of macrofauna (animals $>1 \mathrm{~mm}$ ) and macroalgae species in the upper sandy fringe. Consequently, all further descriptive analyses are valid for the terrace of boulders and cobbles as the main site for the establishment of intertidal macrobenthic communities.

A total of 6 taxonomic groups and 60 species were collected from the four transects. Macroalgae were present with 17 species, polychaetes with 11 , crustaceans with 12 , molluscs with 17 , echinoderms with 2, and one fish species was found. All species of actinians, turbellarians, nematodes, nemerteans, oligochaetes and holothurians were considered as one taxon each (Table 1).

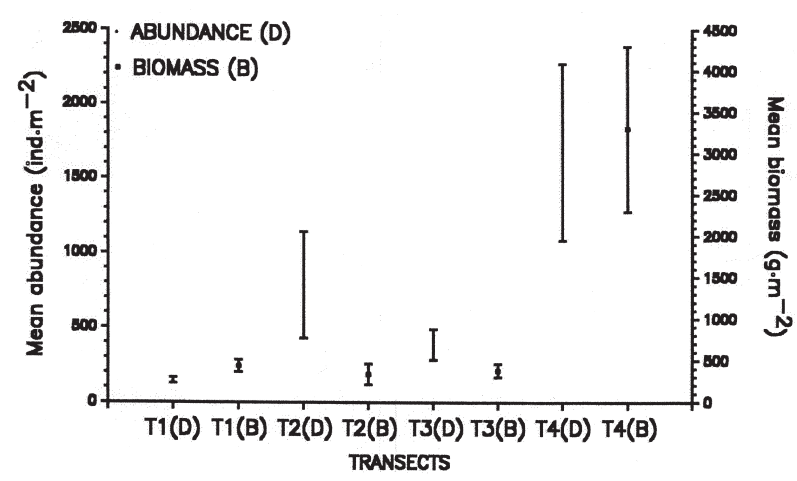

FIG. 3. - Mean biomass (wet weight) and density of macrobenthos in the four transects in Canal Whiteside

Average abundance in terms of number of individuals $\mathrm{m}^{-2}$ varied between 144.7 (transect 1 ) and 1677.3 in transect 4 (Fig. 3). The highest biomass values were obtained in transect $4\left(3300.8 \mathrm{~g} / \mathrm{m}^{-2}\right)$ and the lowest $\left(336.2 \mathrm{~g} / \mathrm{m}^{-2}\right)$ in transect 2 (Fig. 3). Differences in mean abundance and biomass for the four transects were statistically significant (ANOVA; $\mathrm{p}<0.001$ ). The unplanned multiple comparison test LSD applied to the mean number of individuals indicated that values of transect 4 differ significantly from the other three transects $(p<0.05)$, whereas no significant differences occurred between transect 1 and $3(\mathrm{p}=$ $0.286)$ and transect 2 and $3(\mathrm{p}=0.143)$. The same test applied to biomass values showed that transect 4 differed significantly from the other three transects $(\mathrm{p}<$ 0.0001 ), and the differences between transects 1,2 and 3 were not significant ( $\mathrm{p}>0.05$ ).

The composition of species and major taxa also was highly heterogenous between the transects. High dominance of few species or major taxa and high numbers of taxa comprising less than $2 \%$ of the total number of individuals were characteristic of all four transects (Table 2). A high number of species $(n=40)$ was collected in transect 1 , but the dominance of 29 species and major taxa was less than $2 \%$. In this transect the amphipod Paramoera fissicauda was the dominant species (23\%) followed by the bivalves Mytilus chilensis (15\%) and Perumytilus purpuratus (14\%). A total of 11 species and taxonomic groups were collected in transect 2, and P. purpuratus (49\%) and M. chilensis $(47 \%)$ were the numerically dominant species. Both bivalve species were also dominant in transect 3 and 4, and in the later transect, $M$. chilensis represented $89 \%$ of the total number of individuals (Table 2). Both bivalve species seem to develop a single-layer bed. In terms of biomass, a clear dominance of bivalve molluscs was found in all four 
TABLE 2. - Percent dominance in number (N) and biomass (B) of taxa in the four transects (T-1 / T-4) of Canal Whiteside, Tierra del Fuego. Category "Others" includes all animals with dominance $\leq 2 \%$. * indicates presence but $\leq 2 \%$ dominance of the corresponding taxa.

\begin{tabular}{|c|c|c|c|c|c|c|c|c|}
\hline \multirow{2}{*}{$\begin{array}{l}\text { Transects } \\
\text { Taxa }\end{array}$} & \multicolumn{2}{|c|}{$\mathrm{T}-1$} & \multicolumn{2}{|c|}{$\mathrm{T}-2$} & \multicolumn{2}{|c|}{$\mathrm{T}-3$} & \multicolumn{2}{|c|}{ T-4 } \\
\hline & $\mathrm{N}$ & B & $\mathrm{N}$ & B & $\mathrm{N}$ & B & $\mathrm{N}$ & B \\
\hline Paramoera fissicauda & 22.6 & - & & - & 16 & - & - & - \\
\hline Mytilus chilensis & 15.3 & 64.2 & 47.0 & 60.6 & 44.9 & 71.1 & 88.7 & 97.4 \\
\hline Perumytilus purpuratus & 14.3 & 20.0 & 48.9 & 39.0 & 26.7 & 21.1 & $*$ & - \\
\hline Transorchestia chiliensis & 9.3 & - & $*$ & - & - & - & $\stackrel{*}{-}$ & - \\
\hline Paramoera brachyura & 5.2 & - & - & - & 6.6 & - & - & - \\
\hline Hyale hirtipalma & - & - & - & - & $*$ & - & 2.3 & - \\
\hline Nacella magellanica & 4.8 & 7.2 & - & - & - & 5.6 & $*$ & - \\
\hline Nacella deaurata & 4.7 & 4.4 & - & - & - & - & - & - \\
\hline Hemipodus simplex & 2.7 & - & - & - & - & - & - & - \\
\hline Turbellaria & 5.2 & - & - & - & - & - & - & - \\
\hline Nemertini & 2.1 & - & - & - & - & - & - & - \\
\hline Holothuroidea & 2.5 & - & - & - & - & - & - & - \\
\hline Others & 11.9 & 4.2 & 4.1 & 0.4 & 5.6 & 2.1 & 10.0 & 2.6 \\
\hline Total number and biomass (g) & 2324 & 6892 & 5490 & 2389 & 3454 & 3427 & 5032 & 9901 \\
\hline Total number of taxa & 40 & & 11 & & 19 & & 30 & \\
\hline
\end{tabular}

transects, with $M$. chilensis being the dominant species, representing between $61 \%$ (transect 2) and $97 \%$ (transect 4 ) of the total biomass.

A total of 17 macroalgae species were determined for the studied area (see Table 1), however, with high variability in abundance between the four transects. Species number ranged between 3 (transect 4) and 10 (transect 3). On average, Ulva lactu$c a$ was the most abundant species in this area.

Species richness and diversity were not homogeneous (Fig. 4). According to ANOVA applied to each index used, richness $(\mathrm{F}=5.558 ; \mathrm{p}=0.004)$, diversity $(\mathrm{F}=6.03 ; \mathrm{p}=0.002)$ and evenness $(\mathrm{F}=5.858$; $\mathrm{p}=0.003$ ) were significantly different between transects. The unplanned multiple comparison test with LSD suggests possibilities to cluster the transects into different categories according to the utilized index. Richness in transects 2 and 3 was significantly different from values obtained in transects 1 and
4. For $\mathrm{H}^{\prime}$ it is possible to group transects 2,3 , and 4 which differed significantly from transect 1 . Evenness obtained for transect 4 differed significantly from those calculated for transect 1, 2, and 3 .

Measurements of similarity of species abundance between samples by means of cluster descriptive analysis are shown in the dendrograms of Figure 5. High heterogeneity was obtained at stations 1 and 2 in all transects, and relatively high homogeneity at stations 3-4, 5-6 in transect 2 and stations 11-16 in transect 1. Station 7 from transect 3 (with only three species and low abundance each) also has a great dissimilarity compared to all the other sampling stations of the transect. Independant of the similarity level chosen for grouping, stations in all transects can be ordered according to their position on the beach profiles, i.e. no samples from the upper part of the beach are grouped with samples taken down on the shore. At an arbitrary similarity level of $50 \%$,
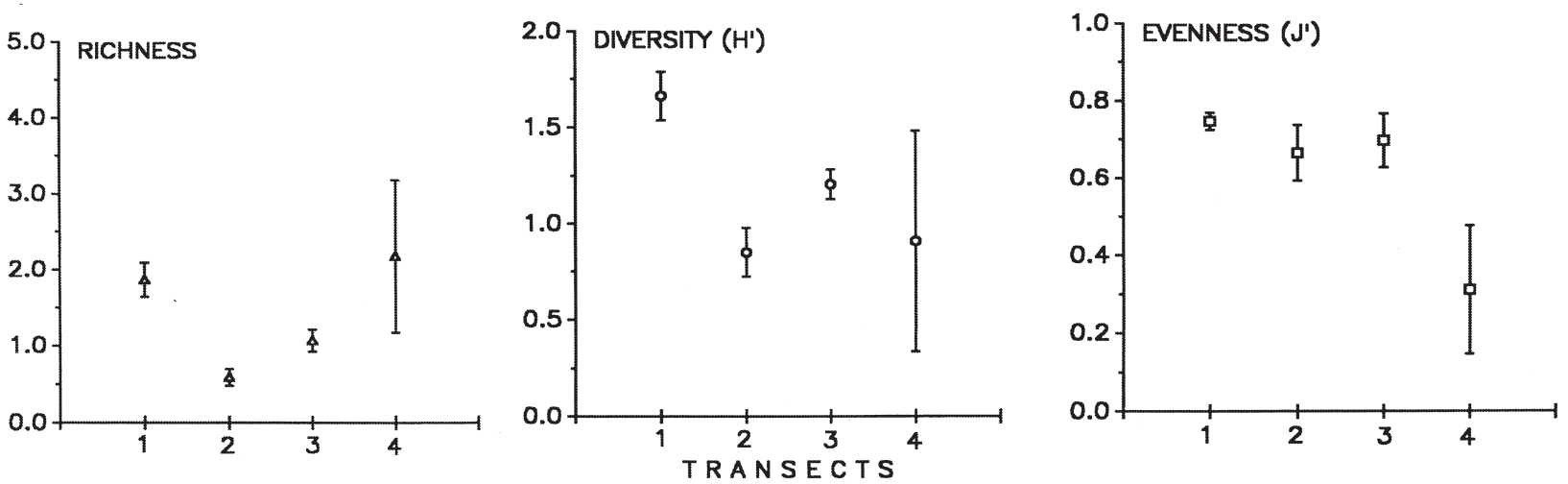

FIG. 4. - Species richness, diversity (H') and evenness (J') based on animal species abundance data along the four studied transects in Canal Whiteside. 

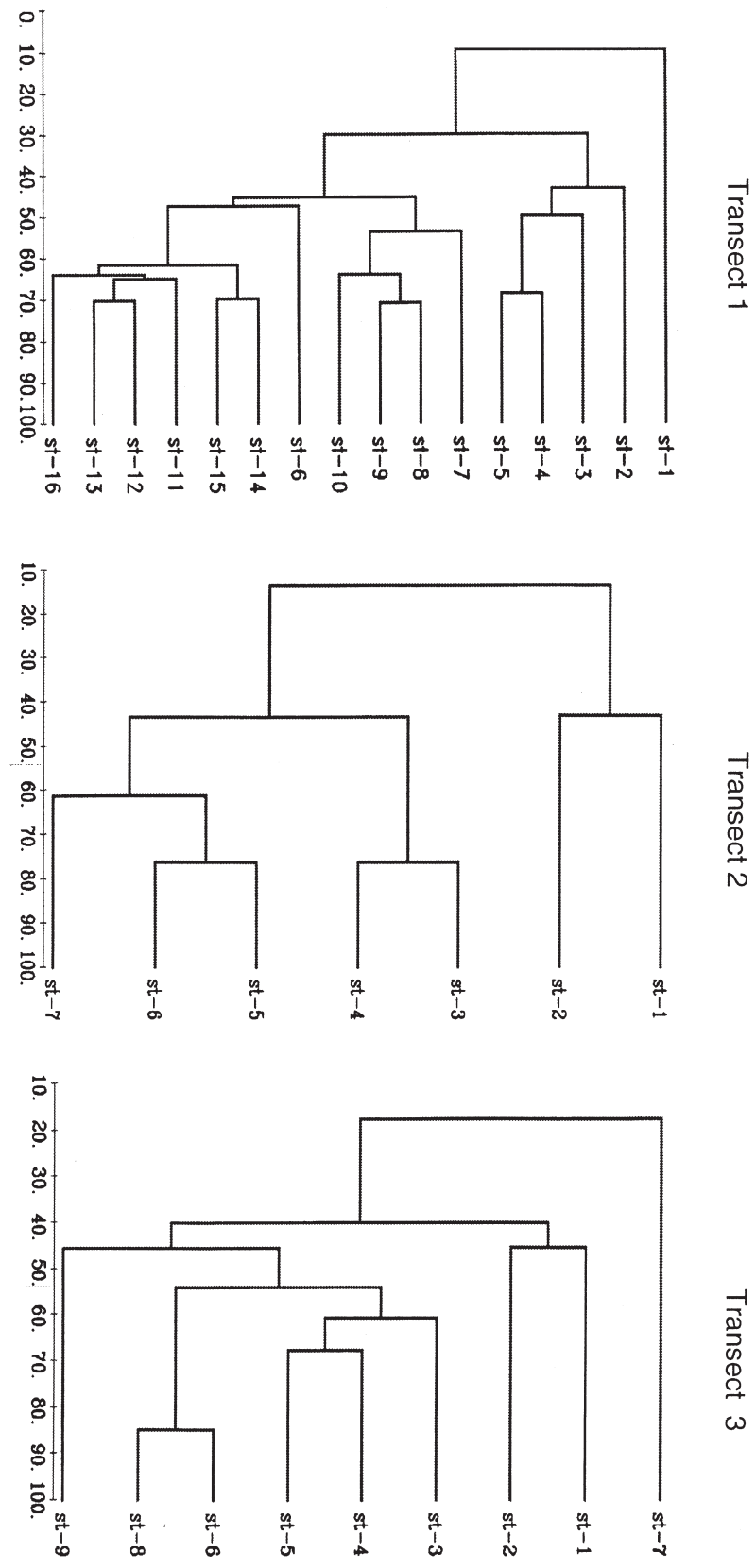

FIG. 5. - Dendrogram of three studied transects, using group similarities -average clustering from Bray-Curtis on double square-root transformed animal species abundances. (ST= sampling station).

samples are divided into 6 groups in transect 1, and 4 in transect 2 and 3 . These groups can be associated with different beach height.

\section{DISCUSSION}

Data on structure and organization of marine intertidal communities are scarce for the Magellan region, although some effort has been made to describe the main features of the assemblages inhabiting the intertidal boulder-cobble system of the region (e.g. Guzmán and Campodónico, 1981; Ríos and Guzmán, 1982; Guzmán and Ríos, 1986; Cornejo, 1996; Ríos and Gerdes, 1997; Benedetti-Cecchi and Cinelli, 1997).

One important feature of this type of intertidal zone is the relatively high level of species richness found with more intensive surveys at some localities. In our study we recognized at least 17 macroalgae species and 44 macrofauna species, even though we excluded from the analysis taxa such as actinians, turbellarians, nematodes, nemerteans, oligochaetes and holothurians due to restricted taxonomic knowledge. In Bahía Laredo, which presents a similar type of physical habitat, Ríos and Gerdes (1997) recognized at least 26 invertebrate species inhabiting the top surface of boulders and cobbles, and the molluscs Mytilus chilensis, Laevilittorina caliginosa, Kerguelenella lateralis, Pareuthria plumbea, Nacella deaurata, Acanthina monodon and Trophon geversianus were most abundant. Cornejo (1996) determined at least 56 macroalgae species in the same area. According to Mutschke et al. (in press) at least 110 benthic species including macroalgae and macrofauna occur in the bouldercobble intertidal zone in the Straits of Magellan inhabiting the top surface of rocks, the interstitial area and fine sediment below the boulders and cobbles. These results are in contrast with those published by Benedetti-Cecchi (1996) and Mazzella and Gambi (1993), who reported both low species richness and diversity for some intertidal zones in the Magellan areas, but based on more restricted and isolated sampling effort.

As has been reported for Subantarctic and Antarctic areas (e.g. Arnaud, 1992) and for the Straits of Magellan (e.g. Ríos and Gerdes, 1997), the biotic assemblages of intertidal boulders and cobbles at Canal Whiteside were highly dominated by one or two species, whereas the others were rare or very rare. In this sense, the studied community can be considered as a Mytilus chilensis-dominated community, with mussels forming a single-layer bed. Interestingly, the microhabitats formed by $M$. chilensis do not enhance species richness by the establishment of specific assemblages of different sessile and mobile organisms, as has been suggested as typical for mussel beds (e.g. Alvarado and Castilla, 1996). Transect 1 , with its lower M. chilensis dominance as compared to the other three transects showed the highest species richness. 
Dominance of mussels in abundance and biomass (mainly Mytilus chilensis and Perumytilus purpuratus) seems to be characteristic of communities in boulder-cobble covered areas in the Magellan Region. Other typical epifauna species of this habitat are the herbivorous limpets of the genus Nacella, which have a wide circumpolar distribution (e.g. South Georgia: Davenport, 1997; Heard Island: Smith and Simpson, 1985; Macquarie Island: Simpson, 1976a). In Antarctic areas, N. concinna is the dominant limpet in some intertidal areas (e.g. Camus, 1995; Knox, 1994; Castilla and Rozbaczylo, 1985). In the Magellan Region, N. magellanica and $N$. deaurata are the dominant species of this genus (e.g. Ríos and Gerdes, 1997; Ríos and Guzmán, 1982). Circumpolar distribution occurs also in other faunal and floral elements of the studied intertidal area. Macroalgae such as Enteromorpha, Porphyra, Adenocystis, Urospora, and Iridaea have been reported for the intertidal zone of Robert Island in the Antartic Peninsula (Castilla and Rozbaczylo, 1985), and Porphyra and Enteromorpha are common in the solid-rock intertidal zone at Macquarie Island (Simpson, 1976b) and Heard Island (Smith and Simpson, 1985). Benthic species like the isopod Exosphaeroma gigas, the chiton Plaxiphora aurata, and also the genus Anasterias (sea star) are present in solid rocky-shore substrates at Macquarie Island, but those types of habitat are largely dominated by macroalgae (Simpson, 1976b). Arnaud (1974) found, in an extensive study of Antarctic and SubAntarctic marine benthos at Kerguelen Island, several animal species, which also occurred at Canal Whiteside, like the brachyuran Halicarcinus planatus and the gammarids Paramoera fissicauda and Hyale hirtipalma. These results are consistent with the biogeographical regions mentioned by Knox (1994) for the benthos of the Southern Ocean, which include the Magellanic sub-region as a Sub-Antarctic District as well as areas located in the eastern part of the Pacific like Heard Island, Macquarie Island and Kerguelen island. Recently, it turned out that the decapod fauna of the southern tip of South America includes species with Antarctic distribution (Arntz et al., 1999).

Although the grouping provided by the cluster analysis must be regarded with a certain degree of caution, our results suggest a clear zonation pattern of species along the transects of a boulder-cobble shore, in contrast to results of Benedetti-Cecchi and Cinelli (1997), who concluded from a small data base the non-existence of a general pattern of zona- tion in the rocky intertidal of the Straits of Magellan. Bahía Laredo, one of the areas studied by Benedetti-Cecchi and Cinelli (1997) and erroneously considered as a (sic) "site with continuous rocky shore", represents a typical boulder and cobble intertidal zone similar to the shore of Canal Whiteside studied by us. For that area, Ríos and Gerdes (1997) reported differences in the vertical distribution of epifaunal species, a pattern also found in Canal Whiteside.

\section{ACKNOWLEDGEMENTS}

This study was partially supported by funds from the Universidad de Magallanes under Grant F3-02B96, and from the Forestal Trillium Ltda. and Bayside Ltda., USA, under Grant $N^{\circ}$ 94-03 supervised by the Scientific Comission for the Rio Condor Project. Most importantly, we are grateful to Prof. Dr. Wolf Arntz and Dr. Dieter Gerdes, from the Alfred Wegener Institute for Polar and Marine Research, Bremerhaven, Germany, for their intensive and insistent input in order to get information regarding the intertidal systems of this impressive region of the world. We must also acknowledge the helpful comments and suggestions on an earlier version of this paper of Drs. Matthias Gorny (Instituto de la Patagonia, Universidad de Magallanes) and Julian Gutt (Alfred Wegener Institute, Bremerhaven).

\section{REFERENCES}

Alvarado, J.L. and J.C. Castilla. - 1996. Tridimensional matrices of mussels Perumytilus purpuratus on intertidal platforms with varying wave forces in central Chile. Mar. Ecol. Prog. Ser., 133: $135-141$.

Arnaud, P.M. - 1974. Contribution a la bionomie benthique des régions antarctiques et subantartiques. Tethys, 6: 465-656.

Arnaud, P.M. - 1992. The state of the art in Antarctic benthic research. In: V.A. Gallardo, O. Ferretti and H. Moyano (eds.), Oceanografía en Antártica, pp. 341-436. Ediciones Documentas, Santiago.

Arntz, W., I. Wehrtmann, M. Gorny, R. Soto, M. Lardies and R. Retamal. - 1999. Species composition and distribution of benthic decapod crustaceans around the southern tip of South America. Sci. Mar., 63(Supl. 1): 303-314.

Benedetti-Cecchi, L. - 1996. Distribution of macroalgae and invertebrate grazers in the Magellan Strait. Ber. Polarforsch., 190: 70-71.

Benedetti-Cecchi, L. and F. Cinelli. - 1997. Spatial distribution of algae and invertebrates in the rocky intertidal zone of the Strait of Magellan: are patterns general? Polar Biol., 18: 337-343.

Brambati, A., G. Fontolan and U. Simeoni. - 1991. Recent sediment and sedimentological processes in the Strait of Magellan. Boll. Oceanol. Teor. Appl., 9: 217-259.

Bray, J.R. and J.T. Curtis. - 1957. An ordination of the upland forest communities of southern Wisconsin. Ecol. Monogr., 27: 325-349.

Buchanan, J.B. - 1984. Sediment analysis. In: N. A. Holme and A. D. McIntyre (eds.): Methods for the Study of Marine Benthos, pp. 41-65. IBP Handbook Nr. 16, 2nd. Edition. Blackwell Sci- 
entific Publications, Oxford, London.

Camus, P.A. - 1995. Size structure and spatial variation of the Antarctic limpet Nacella concinna (Strebel, 1908) on King George Island, South Shetland, Antarctica. Ser. Cient. INACH, 45: $115-122$

Castilla, J.C. and N. Rozbaczylo. - 1985. Rocky intertidal assemblages and predation on the gastropod Nacella (Patinigera) concinna at Robert Island, South Shetlands Antarctica. Ser. Cient. INACH, 32: 65-73

Clapperton, Ch.M., D.E. Sugden, D.S. Kaufman and R.D. McCulloch. - 1995. The last glaciation in Central Magellan Strait, southernmost Chile. Quat. Res., 44:133-148.

Clarke, K.R. and R.M. Warwick.- 1994. Change in Marine Communities: An Approach to Statistical Analysis and Interpretation. Plymouth Marine Laboratory UK, Bournemouth, UK.

Cornejo, S. - 1996. Reporte preliminar de macroalgas presentes en Bahía Laredo, Estrecho de Magallanes. Ans. Inst. Pat., Ser. Cienc. Nat., 24: 87-96.

Davenport, J. - 1997. Comparison of the biology of the intertidal Subantarctic limpets Nacella concinna and Kergelenella lateralis. J. Moll. Stud., 63: 39-48.

Emery, K.O. - 1961. A simple method of measuring beach profiles. Limnol. Oceanogr., 1: 90-93.

Guzmán, L. - 1978. Patrón de distribución espacial y densidad de Nacella magellanica (Gmelin, 1791) en el intermareal del Estrecho de Magallanes (Mollusca, Gastropoda). Ans. Inst. Pat., Ser. Cienc. Nat., 9: 205-219.

Guzmán, L. and I. Campodónico. - 1981. Studies after the Metula oil spill in the Straits of Magellan, Chile. PETROMAR, 80: 363376.

Guzmán, L. and C. Ríos. - 1986. Análisis de la estructura en comunidades intermareales del archipiélago del Cabo de Hornos: ambientes de bloques y cantos. Estud. Oceanol., 5: 67-105.

Guzmán, L. and C. Ríos. - 1987. Age and growth of the Subantarctic limpet Nacella (Patinigera) magellanica magellanica (Gmelin,1791) from the Strait of Magellan, Chile. Veliger, 30: 159-166.

Knox, G.A.- 1994. The Biology of the Southern Ocean (Studies in Polar Research). Cambridge University Press, Cambridge.

Langley, S., L. Guzmán and C. Ríos. - 1980. Aspectos dinámicos de Mytilus chilensis (Hupé, 1840) en el Estrecho de Magallanes. I. Distribución, densidad y disposición espacial en el intermareal. Ans. Inst. Pat., Ser. Cienc. Nat., 11: 319-332.

Mazzella, L. and M.C. Gambi. - 1993. First oceanographic cruise in the Strait of Magellan (February-March 1991): report on benthic populations of the intertidal zone of the Seno Skyring. In: F. Faranda and L. Guglielmo (eds), Oceanographic Cruise February-March 1991, pp. 283-296. Data Rep., Part II. Natl. Comm. Antartica, Genova.

Miranda, O. and E. Acuña. - 1979. Mytilus edulis chilensis (Hupé, 1854) en Cabo Negro (Provincia de Magallanes) (Mollusca, Bivalvia, Mytilidae). Rev. Biol. Mar. Dep. Oceanol. Univ. Chile, 16: 331-353.

Mutschke, E., C. Ríos and A. Montiel. - 1998. Catálogo preliminar de la macrofauna de Bahía Laredo, Estrecho de Magallanes. Ans. Inst. Pat., Ser. Cienc. Nat., 26: 1-12.

Ríos, C. and L. Guzmán. - 1982. Reevaluación de la estructura de la comunidad en una playa de bloques y cantos de alta latitud (archipiélago del Cabo de Hornos). Ans. Inst. Pat., Ser. Cienc. Nat., 13: 211-224.

Ríos, C. and E. Mutschke. - 1995. Estudios intermareales y sublitorales en Canal Whiteside, Tierra del Fuego. Data Rep. Comité Cient. Proyecto Río Cóndor: 1-62.

Ríos, C. and D. Gerdes. - 1997. Ensamble bentónico epifaunístico de un campo intermareal de bloques y cantos en Bahía Laredo, Estrecho de Magallanes. Anst. Inst. Pat., Ser. Cienc. Nat., 25: 47-55.

Ríos, C., C. Noziglia and L. Guzmán. - 1987. Desarrollo larvario de los gastrópodos Siphonaria (Pachysiphonaria) lessoni (Blainville, 1824) y Kerguelenella lateralis (Gould, 1846) (Pulmonata:Siphonariidae) del Estrecho de Magallanes, Chile. Ans. Inst. Pat., Ser. Cienc. Nat., 17: 77-88.

Santana, M. - 1997. Estudio del desarrollo intracapsular de Trophon geversianus (Pallas, 1769) (Gastropoda, Muricidae) bajo condiciones naturales y de laboratorio. Marine Biologist Licenciatura Thesis, Univ. Austral de Chile.

Simpson, R.D. - 1976a. Physical and biotic factors limiting the distribution and abundance of littoral molluscs on Macquarie Island (Sub-Antarctic). J. Exp. Mar. Biol. Ecol., 21: 11-49.

Simpson, R.D. - 1976b. The shore environment of Macquarie Island. ANARE Scient. Rep., Australian Governm. Dept. Sci., Ser. B (1), Zool., 125: 1-41.

Smith, J.M.B. and R.D. Simpson. - 1985. Biotic zonation on rocky shores of Heard Island. Polar Biol., 4: 89-94.

Sokal, R.R. and F.J. Rohlf. - 1995. Biometry: The Principles and Practice of Statistics in Biological Research. Freeman and Co., New York.

Uribe, P. - 1982. Desglaciación en el sector central del Estrecho de Magallanes: Consideraciones geomorfológicas y cronológicas. Ans. Inst. Pat., Ser. Cienc. Nat., 18: 103-113. 